\title{
New developments in the incretin concept
}

\author{
W. Creutzfeldt and R. Ebert \\ Division of Gastroenterology and Metabolism, Department of Medicine, University of Göttingen, FRG
}

\begin{abstract}
Summary. Experimental and clinical work over the last 6 years has confirmed and broadened, but also challenged, the incretin concept. The nervous component of the entero-insular axis is still poorly defined, especially the peptidergic nerves, of which several contain insulinotropic regulatory peptides. The incretin effect is preserved after complete denervation of the porcine pancreas. Type 2 (non insulin-dependent) diabetic patients have a significantly decreased incretin effect. GIP (gastric inhibitory polypeptide; glucose dependent insulin releasing peptide) remains the strongest incretin factor. Its secretion depends on the absorption of nutrients. However, the correlation between the GIP response and disturbances of the entero-insular axis in some gastrointestinal diseases and, in particular, Type 2 diabetes, is poor. Furthermore, physiological concentrations of exogenous GIP do not produce fully the
\end{abstract}

incretin effect and injection of GIP antibodies does not abolish the incretin effect. This suggests the existence of additional humoral incretin factors. On the other hand, GIP seems to have direct metabolic effects independent of its insulinotropic activity. The incretin effect of oral glucose is smaller if plasma levels of $\mathrm{C}$-peptide rather than insulin are measured. However, decreased hepatic extraction of insulin after glucose ingestion only accounts partially for the incretin effect. GIP is unlikely to be the gut factor which regulates hepatic insulin extraction.

Key words: Incretin, entero-insular axis, insulinotropic factors, GIP, hepatic insulin extraction, pancreatic denervation, Type 2 diabetes, experimental diabetes.
More than 6 years have passed since a Claude Bernard Lecture on the incretin concept was published in this journal [1]. Since then many publications related to this subject have appeared. Many have confirmed what was known, some have broadened the concept and some have challenged it. Most investigators agree that important problems are still unsolved, such as the role of the nervous component of the entero-insular axis, especially the peptidergic nerves, and the significance of the entero-insular axis in the pathogenesis of certain diseases [2]. The difficulty of establishing a correlation between the plasma levels of recognized humoral incretin factors and disturbances of the entero-insular axis has raised the question whether other, as yet unknown, incretin factors exist.

\section{Terminology}

The term "incretin", introduced by Zunz and LaBarre in 1929 [3] to describe a humoral activity of the gut that might enhance the endocrine secretion of the pancreas (i. e. insulin), is used in this article only for hormonal stimuli of insulin secretion deriving from the gut. Such a factor should be released by nutrients, especially glucose. The difference between the insulin response after oral and that after a similar glucose load given intravenously is called the incretin effect.

The incretin concept deals with all factors responsible for the higher plasma insulin levels occurring after glucose ingestion as compared to the plasma insulin levels achieved after isoglycemic intravenous glucose infusion. It comes close to the term "entero-insular axis", coined in 1969 by Unger and Eisentraut [4], which comprises all stimuli from the small intestine influencing the islets of Langerhans, including hormonal, neuronal and direct substrate stimulation of insulin, glucagon, somatostatin and pancreatic polypeptide [1].

Recently, much has been learned about the intestinal and nervous regulation of glucagon, somatostatin and pancreatic polypeptide secretion. In addition, there has been much speculation about intra-insular actions (paracrine, or via the islet capillaries) of these peptides on insulin secretion. However, this complex interplay will not be discussed in this review. 
Table 1. Regulatory peptides investigated for their insulinotropic potency, their localization in epithelial cells or neurons and their release by glucose ingestion

\begin{tabular}{|c|c|c|c|c|}
\hline \multirow[t]{2}{*}{ Peptide } & \multicolumn{2}{|c|}{ Localization } & \multirow{2}{*}{$\begin{array}{l}\text { Released } \\
\text { by } \\
\text { glucose }\end{array}$} & \multirow{2}{*}{$\begin{array}{l}\text { insulin } \\
\text { release }\end{array}$} \\
\hline & $\begin{array}{l}\text { Epi- } \\
\text { thelial }\end{array}$ & $\begin{array}{l}\text { Neuro- } \\
\text { nal }\end{array}$ & & \\
\hline Gastrin & + & + & $(+)$ & + \\
\hline $\begin{array}{l}\text { Cholecystokinin } \\
\quad(\text { CCK-4, }-8,-33,-39)\end{array}$ & + & + & 0 & + \\
\hline Secretin & + & 0 & 0 & + \\
\hline $\begin{array}{l}\text { Gastric inhibitory poly- } \\
\text { peptide (GIP) }\end{array}$ & + & 0 & + & + \\
\hline $\begin{array}{l}\text { Gastrin releasing peptide } \\
\text { (GRP) (Bombesin) }\end{array}$ & 0 & + & & + \\
\hline $\begin{array}{r}\text { Vasoactive intestinal } \\
\text { polypeptide (VIP) }\end{array}$ & 0 & + & & + \\
\hline $\begin{array}{l}\text { Peptide histidine } \\
\text { isoleucine (PHI) }\end{array}$ & 0 & + & & + \\
\hline Opioid peptides & 0 & + & & + \\
\hline Enteroglucagon & + & 0 & + & 0 \\
\hline Motilin & + & 0 & 0 & 0 \\
\hline $\begin{array}{l}\text { Pancreatic polypeptide } \\
\text { (PP), Peptide YY (PYY) }\end{array}$ & + & 0 & $(+)$ & 0 \\
\hline Neuropeptide Y (NPY) & 0 & + & & 0 \\
\hline $\begin{array}{l}\text { Thyreotropin releasing } \\
\text { hormone (TRH) }\end{array}$ & 0 & + & & 0 \\
\hline Neurotensin & + & + & $(+)$ & - \\
\hline Substance P & + & + & + & - \\
\hline Somatostatin & + & + & $(+)$ & - \\
\hline
\end{tabular}

$+=$ present $\quad 0=$ absent $\quad-=$ inhibition

The list of gastrointestinal regulatory peptides investigated for insulinotropic activity has continued to increase. Relevant information concerning the regulatory peptides is given in Table 1 to incretin candidates, such as their insulinotropic potency, their localization in nerves or epithelial cells and their responses to oral glucose. This table indicates that only GIP fully qualifies as an incretin in the strictest sense. However, several other insulinotropic epithelial and neuronal peptides may participate in the net incretin effect. For instance, GIP and cholecystokinin (CCK-8) in low doses, which alone exert no effect, possess strong insulinotropic activity when injected together in mice [5]. Furthermore, the importance of the neuropeptides of intrinsic pancreatic nerves for signal transmission or modulation of insulin secretion has not yet been explored.

\section{Nerves and neuropeptides}

For more than 50 years it has been known that vagal stimulation enhances and sympathetic nervous stimulation reduces insulin secretion [6]. Vagal stimulation af-

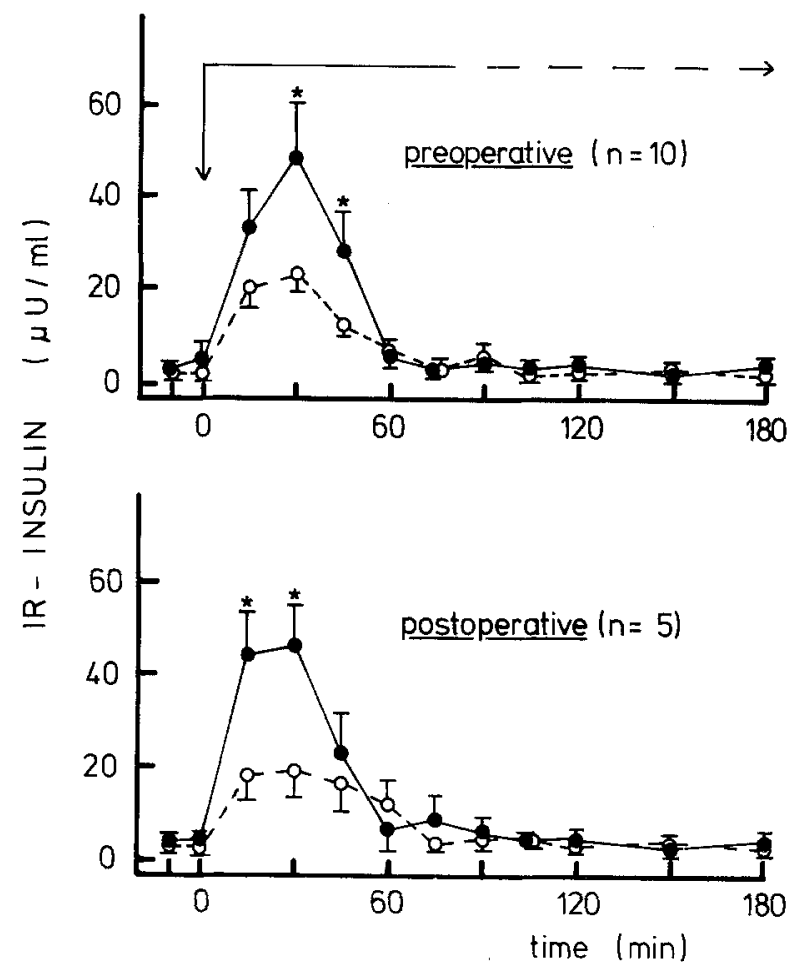

Fig. 1. Arterial plasma insulin after intragastric $(1.5 \mathrm{~g} / \mathrm{kg})$ glucose (- - ) and "isoglycaemic" intravenous glucose infusion $\left(\mathrm{O}_{-} \mathrm{O}\right)$ before (upper panel) and after (lower panel) complete surgical denervation of the pancreas in pigs [17]

ter ingestion of nutrients might augment insulin output, either via cephalic or via gastro-pancreatic and enteropancreatic vago-vagal reflexes, irrespective of the levels of insulinotropic gut hormones. The cephalic phase of insulin secretion is well documented in dogs [7], rats [8, 9] and man [10,11]. In man, the relative contribution of cephalic insulin secretion is still controversial $[12,13]$.

Whether denervation of the pancreas impairs glucose tolerance and reduces the incretin effect has been investigated in several species, by comparing the incretin effect before and after ectopic pancreas transplantation. The data are controversial [14-16]. This may be due partially to organ damage and/or the immunosuppressive treatment given. In a recent study [17], we demonstrated that total denervation of the pancreas in the pig (achieved by extirpation and orthotopic re-implantation) did not alter glucose tolerance and the incretin effect of a glucose load applied via a gastric tube, i.e. by-passing the cephalic phase of insulin release (Fig. 1).

At present, it is unknown whether stimulating cholinergic and inhibiting adrenergic nerves produce a direct effect on the pancreatic islets or whether they only activate intrinsic pancreatic peptiderigic nerves which in turn influence insulin output after ingestion of nutrients. Several gastrointestinal regulatory peptides with insulinotropic inhibitory or stimulating action are present in pancreatic nerves, e.g. stimulators, such as cholecystokinin [18], gastrin [19], enkephalin [20-22], vasoactive intestinal polypeptide (VIP) $[23,24]$ and pep- 
tide histidine isoleucine (PHI) [25, 26], or inhibitors, such as neurotensin [27-29], somatostatin [30], substance $\mathrm{P}[18,27,31]$ and galanin [32].

The peptidergic nervous system, as well as adrenergic and cholinergic nerves, may also regulate the release of duodenal factors with incretin activity. For instance, the secretion of the insulinotropic hormone, GIP, is under vagal [33] and adrenergic control [34].

\section{New data on GIP}

GIP has remained the strongest incretin candidate. New data have accumulated to support its role as an insulinotropic factor. The insulinotropic activity of natural porcine GIP is closely related to the $\mathrm{N}$-terminal residues, the amino acids in position 1 (tyrosine) and 2 (alanine). The previously available GIP preparations contained, in addition, a minor fraction of GIP, consisting of $\mathrm{GIP}_{3-42}$. This component displays no insulinotropic action $[35,36]$. On the other hand, synthetic GIP, corresponding to the sequence 1-38 of porcine GIP, has full insulinotropic activity [37], thereby demonstrating that amino-acids 39-42 are not necessary for this biological effect. Recently GIP has also been isolated from human [38] and bovine [39] intestine. The human form differs from the porcine in two positions and from the bovine in one position. By using specific monoclonal GIP antibodies and an immune gold technique, a single type of cell, showing round homogenous osmophile granules with a closely applied membrane and a mean size of $188 \mathrm{~nm}$, has been identified as the GIP cell [40].

\section{Dependency of GIP secretion on nutrient absorption}

Knowledge on the mechanism of the dependency of GIP release on absorption has been extended. It is known that a prerequisite for GIP release by monosaccharides is the active transport of the monosaccharide into the cell and/or its intracellular metabolism. Certain monosaccharides, which are not actively transported, such as mannose, or not metabolized, such as 2-deoxyglucose, do not stimulate GIP secretion [2, 41, 42].

Acarbose, an $\alpha$-glucosidase inhibitor, was found to drastically curtail the insulin and GIP response in man to a liquid test meal or an oral sucrose load [43]. Osmoreceptors probably do not trigger GIP output, since hyperosmolaric solutions of mannitol were not capable of increasing plasma concentrations of GIP $[44,45]$. Dependency of GIP release on absorption of sugars may be one safeguard protecting the body against potential hypoglycaemia [1]. Ingestion of fat (corn oil) produces a large rise in the concentration of GIP [46, 48], which often lasts more than $4 \mathrm{~h}$. In contrast to oral glucose, the fat-induced GIP increment is not associated with a concomitant rise in plasma insulin because, as another possible safeguard against hypoglycaemia, under normo-

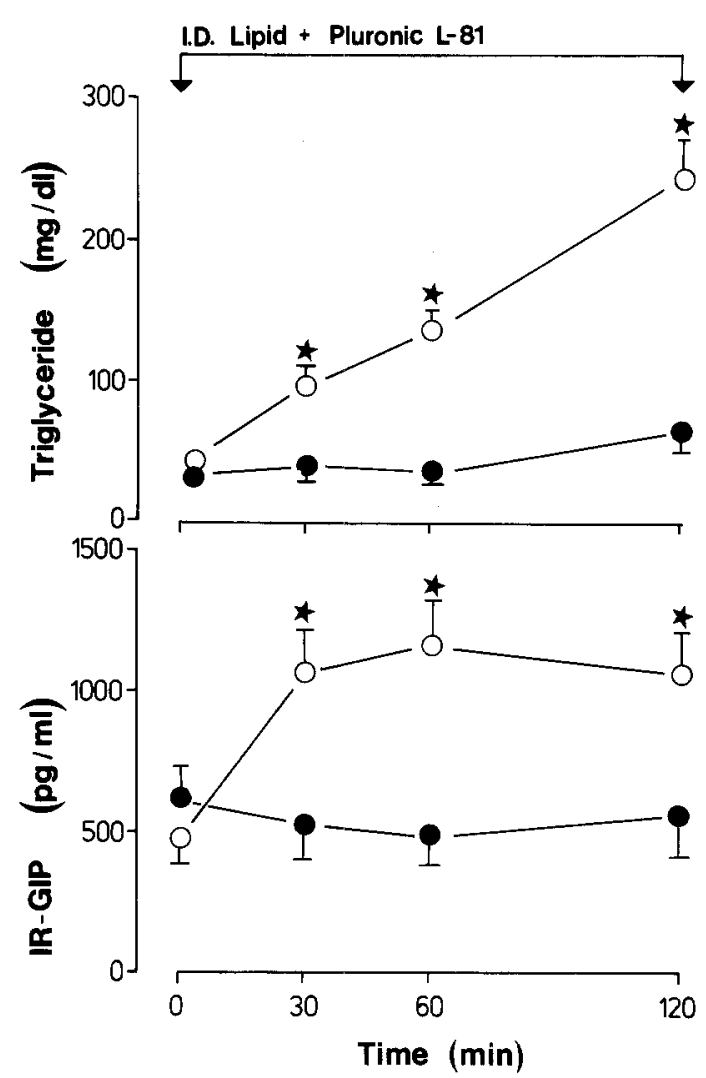

Fig. 2. Serum levels of triglyceride and GIP in rats after an intraduodenal fat load $(0.8 \mathrm{~g} / \mathrm{h})$ with $(\longrightarrow)$ and without $(\mathrm{O}-\mathrm{O})$ the hydrophobic surfactant, Pluronic L81 $(2.0 \mathrm{mg} / \mathrm{h})$ [50]. To convert plasma triglyceride values to millimoles per liter, multiply by 0.0113

glycaemic conditions, GIP does not exert an insulinotropic effect [49].

An increase in GIP levels only follows intraduodenal infusion of long-chain, but not medium-chain triglycerides [50-52]. Since long-chain triglycerides are transported by chylomicrons, whereas medium-chain triglycerides are directly absorbed, fat-induced GIP secretion might, to some extent, be coupled with chylomicron formation. Evidence for this contention was provided recently by experiments with Pluronic L-81 [50], an agent which does not impair triglyceride absorption, but blocks the formation of chylomicrons within gut cells [53]. Under these conditions (e.g. completely blocked chylomicron formation) the GIP response to intraduodenal fat in rats was completely abolished (Fig. 2).

\section{Feedback control between GIP and insulin}

A negative feedback loop between GIP and insulin secretion has been proposed [46], because the fat-induced increment in plasma GIP is markedly attenuated by the simultaneous intravenous infusion of glucose $[47,54$, $55]$ and insulin $[46,56]$. The GIP increment after oral glucose could not be prevented by endogenous [49] or exogenous insulin [56]. Furthermore, rat C-peptide, so 


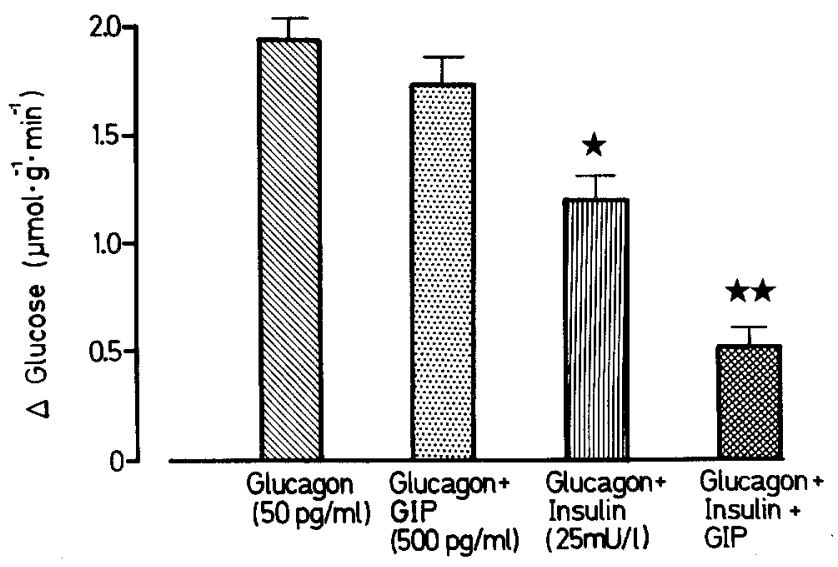

Fig.3. Effect of porcine GIP on hepatic glucose output from the isolated perfused rat liver. The livers were perfused with a glucose concentration of $8.9 \mathrm{mmol} / 1$ in the presence of glucagon $(50 \mathrm{pg} / \mathrm{ml})$, glucagon and GIP $(500 \mathrm{pg} / \mathrm{ml})$, glucagon and insulin $(25 \mathrm{mU} / \mathrm{l})$ and glucagon, GIP and insulin in combination. The increment in hepatic glucose output due to glucagon was calculated as $\mu \mathrm{mol}$ glucose $\cdot \mathrm{g}^{-1}$ liver wet weight $\cdot \min ^{-1}$. Perfusions were performed over $45 \mathrm{~min}$. Each bar represents 11 experiments. ${ }^{*} p<0.005$ versus glucagon alone. ${ }^{* *} p<$ 0.005 versus glucagon plus insulin

far believed to be a biologically inactive substance, completely abolished the GIP response to intraduodenal triglyceride in rats [57]. The fact that fat-induced GIP release is under the control of insulin/C-peptide, whereas the glucose-induced GIP secretion is not, has given rise to the following speculations.

Teleologically, it could be argued that the organism needs protection against an insulin-releasing agent only in the normoglycaemic state, e.g. after oral fat, but not after oral glucose. This finding may also indicate that GIP-producing cells in the gut have separate glucose and fat receptors and that only the fat receptor responds to insulin. Under hyperglycaemic clamp conditions, the GIP response to oral fat was found to be suppressed and, during a hypoglycaemic clamp, it was enhanced [58]. From these results it has been concluded that the fat-induced GIP response is not controlled by the insulin levels, but rather by the arterial blood glucose level. However, it has been demonstrated that preceding hyperinsulinaemia, as produced in these clamp studies, prevents the suppression of the GIP response by insulin and thereby masks the negative feedback inhibition of fat-induced GIP release by insulin [59].

\section{Direct metabolic effects of GIP}

Most of the metabolic effects of GIP can be explained by its insulinotropic action. However, additional metabolic effects have been described in the absence of insulin. In isolated rat fat cells, GIP strongly inhibited the lipolytic action of glucagon. Simultaneously, the glucagon-induced increase of cyclic AMP was also blocked by GIP $[60,61]$. Recent data indicate that GIP also exerts an effect on hepatic glucose production. In dogs with chronic portal venous catheters, GIP reduced hepatic glucose output without a concomitant increase in plasma insulin [62]. In the isolated perfused rat liver, even pharmacological doses of GIP were unable to inhibit the glycogenolytic effect of glucagon. However, in the presence of small amounts of insulin $(25 \mathrm{mU} / \mathrm{l})$ physiological concentrations of GIP reduced the glucagon-induced hepatic glucose output in a dose dependent manner (Fig. 3) [63].

The fat-induced GIP release, which, in the normoglycaemic state, has no effect on insulin secretion, may be directly related to effects of GIP on fat metabolism. Thus, GIP stimulates lipoprotein lipase activity in cultured pre-adipocytes [64]. By this mechanism, triglyceride uptake would be accelerated. In dogs, infusion of GIP in concentrations which mimick the response to an oral fat load, significantly lowered the triglyceride levels attained during simultaneous chylomicron infusion [65]. This effect seems to be restricted to the removal of chylomicron triglycerides, since GIP had no effect on the removal of an intravenously infused triacylglycerol emulsion [66]. If an effect of GIP on chylomicron disposal can be confirmed, the coupling of GIP secretion to chylomicron formation during triglyceride absorption is biologically comprehensive and may become of clinical significance [50].

\section{Pathology of GIP secretion}

One factor in the pathogenesis of the well established hyperinsulinaemia of obesity may be an overactive enteroinsular axis. An exaggerated release of GIP has been observed, together with increased insulin secretion, in obese subjects after ingestion of a high caloric liquid test meal $(1031 \mathrm{kcal})$ or a large oral fat load $(100 \mathrm{~g}$ triglycerides) but not, however, after a $100-\mathrm{g}$ glucose load [67].

The hypersecretion of GIP in obesity after nutrient ingestion has been confirmed [68-70], while other workers found similar or even smaller post-cibal GIP responses in obesity compared with lean healthy subjects [71-74].

These discrepant results may, in part, be due to the different test meals used (solid or liquid; different calories and volumes). It is unlikely that the different antibodies used are the reason for these conflicting results. The amount of GIP released depends on the amount of food entering the duodenum. A more rapid gastric emptying rate as seen in duodenal ulcer patients $[75,76]$ and after gastric surgery [77-79] would explain an exaggerated GIP secretion.

In accordance with this assumption, we observed in obese subjects, the augmented GIP release only after the ingestion of $550 \mathrm{ml}$ of a high caloric test meal (1031 kcal) but not, however, if only $225 \mathrm{ml}$ of the test meal was consumed (Fig.4). Obviously, the stomach of obese, but not of normal, subjects responds to a high 


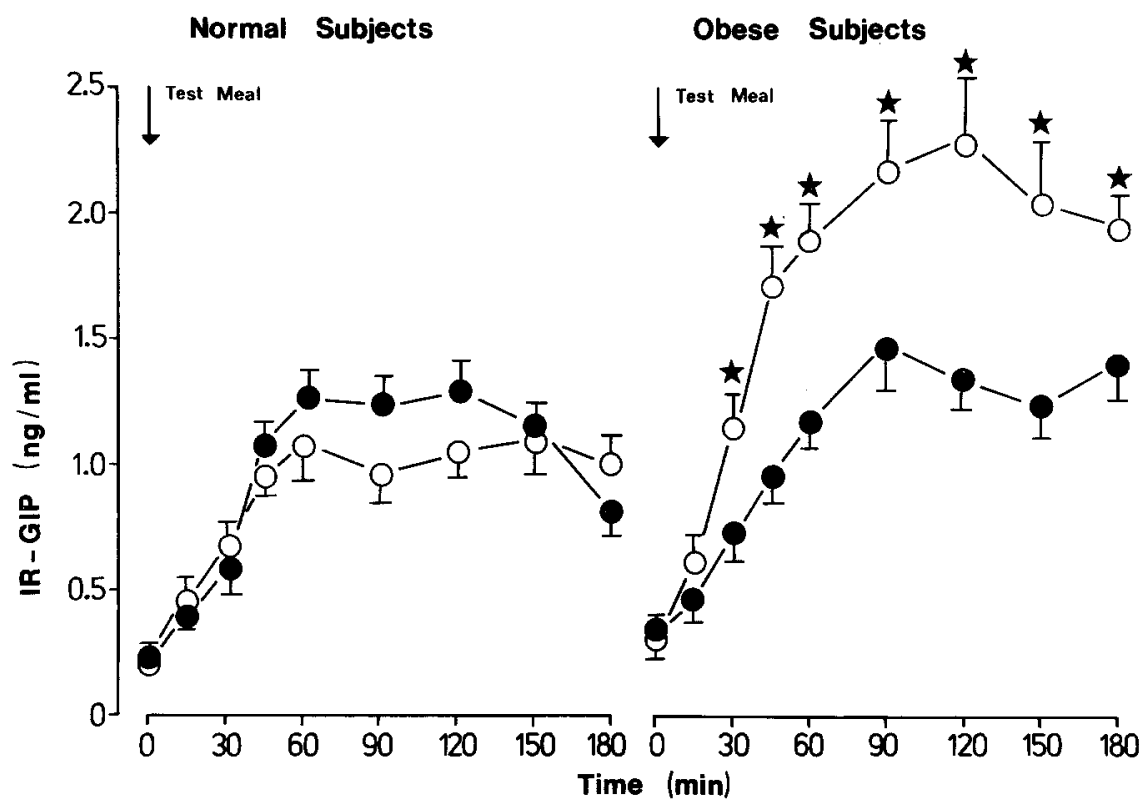

Fig.4. Plasma GIP levels in 10 normal subjects and 10 obese subjects after ingestion of 550 $(\mathrm{O}-\mathrm{O})$ and $225(\longrightarrow) \mathrm{ml}$ of a high caloric liquid mixed test meal. $550 \mathrm{ml}$ contain 1031 and $225 \mathrm{ml} 420 \mathrm{kcal}^{*} p<0.05$ or less versus the $225 \mathrm{ml}$ meal

volume liquid meal by an increased gastric emptying rate leading to an exaggerated GIP response. In all investigations in which GIP response in obesity was normal, the test meal composition had a much lower caloric density and/or a smaller volume or consisted only of glucose.

In well-controlled Type 1 (insulin-dependent) diabetes, GIP secretion is not altered. In Type 2 diabetes, hypersecretion of GIP has been demonstrated following oral glucose or a test meal [80-84]. In two recent studies, a diminished response of GIP to either oral glucose [69] or a solid/liquid meal [74] was described. In the study of Elahi et al. [69], the GIP response after glucose ingestion was exaggerated, but due to very high basal GIP levels, the relative change from basal was smaller than in controls. We studied a large group of Type 2 diabetic patients $(n=141)$ and found both hyper- and hyposecretion of GIP [2] (Fig. 5). Scattergrams of the data revealed a bimodal distribution with a large group having GIP hypersecretion and a smaller group with GIP hyposecretion. No correlation existed between GIP and insulin response when both groups were analyzed. These results do not support the view that in certain Type 2 diabetic patients impaired glucose tolerance is causally related to diminished GIP secretion. The reason for the low GIP response in some Type 2 diabetic subjects is not known. However, it should be considered that treatment (starvation, diabetic diet, insulin therapy) may greatly influence the GIP response in these patients. Cataland and O'Dorisio [85] demonstrated that prior diet composition may have an important effect on postprandial GIP release. Consumption of natural food with $30 \%$ sucrose in normal man markedly augmented the subsequent GIP response to sucrose compared with the same subjects placed on a wheat starch-containing isocaloric diet.

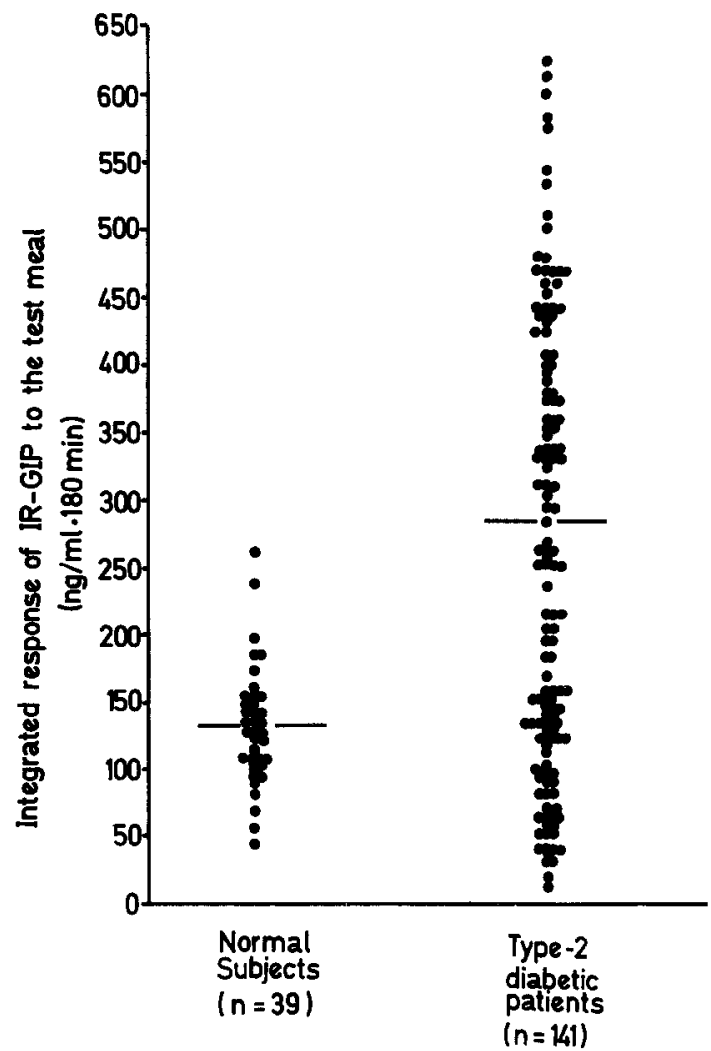

Fig.5. Scattergram of the integrated GIP response to a high caloric mixed liquid test meal $(1031 \mathrm{kcal})$ in 39 normal subjects and 141 patients with Type 2 diabetes [2]

\section{Quantification of incretin}

The incretin effect, first studied by Perley and Kipnis [86], is defined as the ratio between the integrated insulin response to an oral glucose load and to an isoglycaemic intravenous glucose infusion. These authors found 

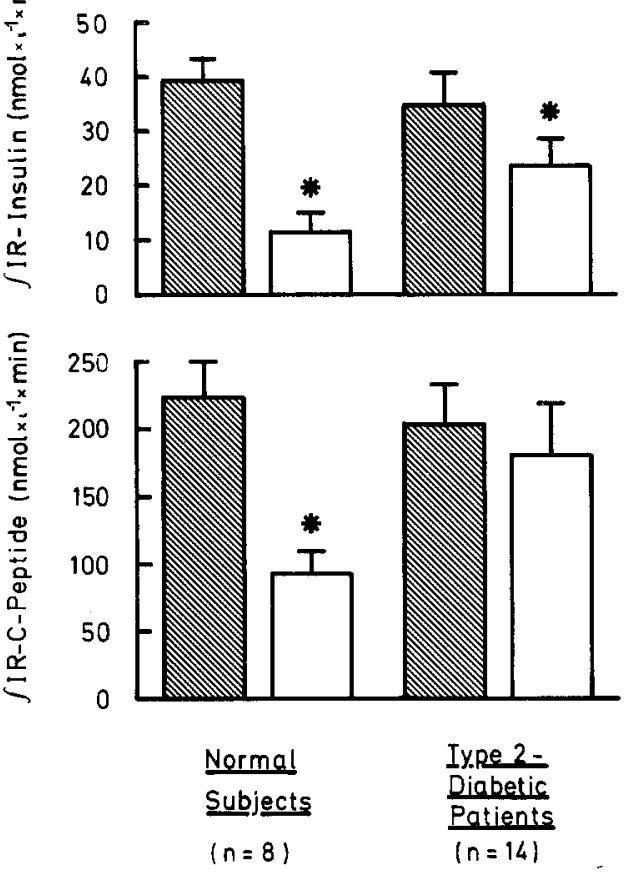

Fig. 6. Integrated incremental responses of immunoreactive insulin and C-peptide to oral glucose $(50 \mathrm{~g} / 400 \mathrm{ml})$ (shaded columns) and respective isoglycaemic intravenous glucose infusions (white columns) are shown for 14 Type 2 diabetic patients and eight age- and weightmatched metabolically healthy subjects. Integration was carried out over $180 \mathrm{~min}$. Data are given as mean $\pm \mathrm{SEM}$. $* p<0.05$ : significant differences (Student's t-test) to respective values after the oral glucose load. Incretin effects are estimated by relating the difference between integrated incremental responses to oral and isoglycaemic intravenous glucose loads to the response after the oral load $(=100 \%)$

no major change in the incretin effect in patients with impaired glucose tolerance. We have tried to correlate the incretin effect with the GIP response obtained in Type 2 diabetic patients and observed that the incretin effect was markedly diminished while the GIP output was not [2]. This could be also confirmed and extended by estimating the C-peptide response (Fig. 6). In this recent investigation, subjects with GIP hyper-, normoand hyposecretion were included. However, no correlation existed between incretin effect and GIP response.

One reason for the discrepancy between GIP response and incretin effect might be that the insulinotropic peptide GIP is unable to stimulate insulin secretion in diabetes due to a defect of the pancreatic $B$ cells. In this context, it is of interest that Type 2 diabetic patients do not respond with sufficient insulin secretion to intravenous injection of impure cholecystokinin (CCK) [87] or porcine GIP $[88,89]$, while the insulin response to intravenous secretin is intact. Alternatively, the decreased incretin effect in Type 2 diabetic patients could be caused by a defective neural transmission or the lack of incretins other than GIP, thereby explaining the reduced activity of the entero-insular axis.

Lauritsen et al. [72, 76, 90] investigated the incretin effect in several gastrointestinal conditions. In coeliac disease during remission, i.e. after improved glucose absorption, the incretin effect of $50 \mathrm{~g}$ glucose was normal despite a markedly reduced GIP response [90]. A similar discrepancy between the incretin effect of oral glucose and the GIP response was seen after jejunoileal bypass operation [72]. In duodenal ulcer patients, however, an increased incretin effect and augmented plasma GIP levels correlated closely [76]. The authors concluded from their results that incretins other than GIP may exist, and that these incretins are located in the distal intestine.

\section{Evidence for the existence of additional insulinotropic factors}

Some investigators have presented data which cast doubt on the unique role of GIP as the only incretin. Sarson et al. [91] compared the insulin response after a 50 -g oral glucose load with that occurring after a combined intravenous infusion of glucose and GIP in providing doses similar to the oral load. They observed that, in normal subjects, the intravenous infusion of GIP and glucose produced an insulin response which was only $40 \%$ of that occurring after oral glucose. They concluded that additional insulinotropic gut factors, including neural modulation, might participate in the higher insulin response after oral glucose. In another study [92], it was demonstrated that the concentration of exogenous GIP and of intravenous glucose required to produce significant potentiation of the insulin response appears to be in the pharmacological, rather than the physiological, range.

The physiological significance of GIP has also been examined by neutralizing endogenous GIP by means of an antibody injection in rats. The insulin response to oral glucose was only partially reduced by injection of GIP antiserum in rats [93]. In these experiments not more than $20 \%$ of the total incretin effect could be related to GIP. In control experiments GIP antiserum was able to antagonize completely the effect of exogenous GIP on insulin release. In contrast to this result, Lauritsen et al. [94] produced a complete blockade of the incretin effect in rats after pretreatment with GIP antibody. This discrepancy was probably caused by the fact that the antibody used in the latter study was raised against crude GIP and, therefore, may have neutralized additional, as yet unknown, insulinotropic gut factors. Gut extracts from which GIP was removed by immunoabsorption [53] released about 50\% less insulin than GIP-containing preparations, thereby demonstrating that a significant part of the incretin effect is due to gut factors other than GIP. However, it has to be remembered that such gut extracts also contain neuropeptides with insulin-releasing potency, like VIP or PHI. Levin et al. [96] demonstrated incretin effects in a perfused rat gut-pancreas preparation after intraduodenal instillation of electrolyte solutions or mannitol. In man, inges- 
tion of mannitol has also been shown to augment glucose-induced insulin output [97]. These effects are certainly not due to GIP release, since mannitol or hyperosmolar electrolyte solutions are not capable of releasing GIP [45]. The authors have also demonstrated that the insulinotropic effect of mannitol only became significant if hyperosmolar solutions were tested. They concluded that increased distension of the upper gut releases a nutrient-independent incretin which may condition the islets prior to nutrient absorption [97]. Analysis of these factors has not yet been performed. Furthermore, the insulin-releasing gut factors described by Zermatten and Felber [98] and Moody [99] other than GIP have not yet been characterized.

\section{Increased secretion or decreased hepatic extraction of insulin?}

Elevated serum levels of insulin do not necessarily prove an increased rate of insulin secretion. Changes in the rate of hepatic insulin extraction during nutrient ingestion would have the same result. Insulin is extracted by more than $50 \%$ during a single hepatic passage [100]. Therefore, any alteration of the hepatic extraction rate can alter significantly plasma insulin levels and thereby alter the incretin effect. C-peptide, unlike insulin, is not degraded by the liver $[101,102]$. Hence, the estimation of C-peptide gives a better measure of changes in the insulin secretion rate. On these grounds, recent investigations have claimed that the role of incretin(s) for the augmentation of insulin secretion has been greatly overestimated [103, 104], and it has been proposed that a major part of the incretin effect is due to decreased hepatic insulin extraction. In addition, the existence of a special gut factor has been suggested which may regulate this process [105]. The nature of this factor is unknown; exogenous GIP was without effect in changing insulin or C-peptide extraction in dogs [106]. The intraportal infusion of cholecystokinin (CCK), however, diminished the insulin degradation rate [107]. It is certainly advisable to re-evaluate some of the incretin work and to estimate insulin and C-peptide simultaneously in future studies on the incretin effect. On the other hand, caution is required in the interpretation of the C-peptide: insulin molar ratio because the assumptions made in these calculations have not yet been proven [102].

\section{References}

1. Creutzfeldt W (1979) The incretin concept today. Diabetologia 16:75-85

2. Creutzfeldt W, Ebert R, Nauck M, Stöckmann F (1983) Disturbances of the entero-insular axis. Scand $\mathrm{J}$ Gastroenterol 18 (Suppl 83): 111-119

3. Zunz E, LaBarre J (1929) Contributions à l'étude des variations physiologiques de la sécrétion interne du pancreas: relations entre les sécrétions externe et interne du pancréas. Arch Int Physiol Biochim 31: 20-44
4. Unger RH, Eisentraut AH (1969) Entero-insular axis. Arch Intern Med 123: 261-266

5. Ahren B, Hedner P, Lundquist I (1983) Interaction of gastric inhibitory polypeptide (GIP) and cholecystokinin (CCK-8) with basal and stimulated insulin secretion in mice. Acta Endocrinol 102: 96-102

6. Woods SC, Porte D Jr (1974) Neural control of the endocrine pancreas. Physiol Rev 54: 596-619

7. Hommel H, Fischer U, Retzlaff K, Knöfler H (1972) The mechanism of insulin secretion after oral glucose administration. II. Reflex insulin secretion in conscious dogs bearing fistulas of the digestive tract by sham-feeding of glucose or tap water. Diabetologia $8: 111-116$

8. Louis-Sylvestre J (1978) Relationship between two stages of prandial insulin release in rats. Am J Physiol 235: E103-E111

9. Siegel EG, Trimble ER, Renold AE, Berthoud HR (1980) The importance of preabsorptive insulin release on oral glucose tolerance: studies in pancreatic islets transplanted rats. Gut 21: 1002-1009

10. Goldfine JD, Abraira C, Gruenewald D, Goldstein MS (1970) Plasma insulin during imaginary food ingestion under hypnosis. Proc Soc Exp Med 133: 274-278

11. Parra-Covarrubias A, Rivera-Rodriguez J, Almarez-Ugalde A (1971) Cephalic phase of insulin release in obese adolescents. Diabetes 20: 800-806

12. Sjöström L, Garellick G, Krotkiewski M, Luyckx A (1980) Peripheral insulin in response to the sight and smell of food. Metabolism 29: 901-909

13. Taylor JL, Feldman M (1982) Effect of cephalic-vagal stimulation on insulin, gastric inhibitory polypeptide, and pancreatic polypeptide release in humans. J Clin Endocrinol Metab 55: 1114-1117

14. Gibby OM, Loke M, Sarson DL, Bloom SR, McMaster P, Colne RY (1980) Disruption of the entero-insular axis in pancreatic transplantation. Regul Pept 1 (Suppl 2): $42 \mathrm{~A}$

15. Jakob A, Largiadèr $F$, Froesch ER (1970) Glucose turnover and insulin secretion in dogs with orthotopic pancreatic allograft. Diabetologia 6: 441-444

16. Lindkaer Jensen $S$, Vagn Nielsen $O$, Kühl C (1976) The enteral insulin-stimulation after pancreas transplantation in the pig. $\mathrm{Di}$ abetologia 12: 617-620

17. Nauck M, van Hoorn W, Gubernatis G, Ebert R, Siewert JR, Creutzfeldt W (1985) Preserved incretin effect after complete surgical denervation of the pancreas in young pigs. Res Exp Med 185: 291-298

18. Larsson LI, Rehfeld JF (1979) Peptidergic and adrenergic innervation of pancreatic ganglia. Scand J Gastroenterol 14: 433-437

19. Larsson LI (1979) Innervation of the pancreas by substance $P$, enkephalin, vasoactive intestinal polypeptide and gastrin/CCK nerves. J Histochem Cytochem 27: 1283-1284

20. Alumets J, Hakanson R, Sundler F, Chang KJ (1978) Leu-enkephalin-like material in nerves and enterochromaffin cells in the gut. An immunohistochemical study. Histochemistry 56: 187-196

21. Hart IC, Cowie AT (1978) Effect of morphine, naloxone and an enkephalin analogue on plasma prolactin, growth hormone, insulin and thyroxine in goats. J Endocrinol 77: 16-17P

22. Ipp E, Dobbs R, Unger RH (1978) Morphine and $\beta$-endorphine influence the secretion of the endocrine pancreas. Nature 276 : 190-191

23. Larsson LI, Fahrenkrug J, Holst JJ, Schaffalitzky de Muckadell OB (1978) Innervation of the pancreas by vasoactive intestinal polypeptide (VIP) immunoreactive nerves. Life Sci 22: 773-780

24. Schebalin M, Said SI, Makhlouf GM (1977) Stimulation of insulin and glucagon secretion by vasoactive intestinal peptide. Am J Physiol 232: E197-E200

25. Christofides ND, Adalaja AB, Tatemoto K, Ferri GL, Polak JM, Bloom SR (1982) Presence of PHI in the human intestine. Regul Pept 3: 69-72

26. Szecowka J, Lins PE, Tatemoto K, Efendic S (1983) Effects of porcine intestinal heptacosapeptide and vasoactive intestinal 
polypeptide on insulin and glucagon secretion in rats. Endocrinology 112: 1469-1473

27. Brown JC, Vale W (1976) Effects of neurotensin and substance $P$ on plasma insulin, glucagon and glucose levels. Endocrinology 98: 819-823

28. Feurle GE, Reinecke M (1983) Neurotensin interacts with carbachol, secretin, and caerulein in the stimulation of the exocrine pancreas of the rat in vitro. Regul Pept 7:137-143

29. Fletcher DR, Blackburn AM, Adrian TE, Chadwick VS, Bloom SR (1981) Effect of neurotensin on pancreatic function in man. Life Sci 29: 2157-1261

30. Hökfeldt T, Efendic S, Hellerström C, Johansson O, Luft R, Arimura A (1975) Cellular localization of somatostatin in endocrine-like cells and neurons of the rat with special references to the $A_{1}$-cells of the pancreatic islets and to the hypothalamus. Acta Endocrinol 80 (Suppl 299): 1-41

31. Bertaccini G (1980) Peptides of the amphibian skin active on the gut. I. Tachykinins (substance P-like peptides) and ceruleins. Isolation structure and basic functions. In: GBJ Glass (ed) Gastrointestinal hormones. Raven Press, New York, pp 315-341

32. McDonald TJ, Dupré J, Tatemoto K, Greenberg GR, Radziuk J, Mutt V (1985) Galanin inhibits insulin secretion and induces hyperglycemia in dogs. Diabetes 34: 192-196

33. Larrimer JN, Mazzaferri EL, Cataland S, Mekhjian HS (1978) Effect of atropine on glucose-stimulated gastric inhibitory polypeptide. Diabetes 27: 638-642

34. Flaten O, Sand T, Myren J (1982) Beta-adrenergic stimulation and blockade of the release of gastric inhibitory polypeptide and insulin in man. Scand J Gastroenterol 17: 283-288

35. Brown JC, Dahl M, Kwauk S, McIntosh CHS, Müller M, Otte SC, Pederson RA (1981) Properties and actions of GIP. In: SR Bloom, JM Polak (eds) Gut hormones, 2nd edn. Churchill Livingstone, Edinburgh, pp 248-255

36. Moody AJ, Damm Jörgensen K, Thim L (1981) Structure-function relationships in porcine GIP. Diabetologia 21: 306 A

37. Moroder L, Hallett A, Thamm P, Wilschowitz L, Brown JC, Wünsch E (1978) Studies on gastric inhibitory polypeptide: synthesis of the octatriacentapeptide GIP ${ }^{1-38}$ with full insulinotropic activity. Scand J Gastroenterol 13 (Suppl 49): 129 A

38. Moody AJ, Thim L, Valverde I (1984) The isolation and sequencing of human gastric inhibitory polypeptide (GIP). FEBS Lett 172: $142-149$

39. Carlquist M, Maletti M, Jörnvall H, Mutt V (1984) A novel form of gastric inhibitory polypeptide (GIP) isolated from bovine intestine using a radioreceptor assay. Eur J Biochem 145: 573-577

40. Usellini L, Capella C, Solcia E, Buchan AMJ, Brown JC (1984) Ultrastructural localization of gastric inhibitory polypeptide (GIP) in a well characterized endocrine cell of canine duodenal mucosa. Histochemistry 80: 85-89

41. Ebert R, Creutzfeldt W (1980) Decreased GIP secretion through impairment of absorption. Front Horm Res 7: 192-201

42. Sykes S, Morgan LM, English J, Marks V (1980) Evidence for preferential stimulation of gastric inhibitory polypeptide secretion in the rat by actively transported carbohydrates and their analogues. J Endocrinol 85: 201-207

43. Fölsch UR, Ebert R, Creutzfeldt W (1981) Response of serum levels of gastric inhibitory polypeptide and insulin to sucrose ingestion during long-term application of acarbose. Scand $J$ Gastroenterol 16: 629-632

44. Martin EW, Sirinek KR, Crockett SE, O'Dorisio TM, Mazzaferri EL, Thomford NR, Cataland S (1975) Release of gastric inhibitory polypeptide: caomparison of hyperosmolar carbohydrate solutions as stimuli. Surg Forum 26: 381-382

45. O'Dorisio TM, Spaeth JT, Martin EW, Sirinek KR, Thomford NR, Mazzaferri EL, Cataland S (1978) Mannitol and glucose: effects on gastric acid secretion and endogenous gastric inhibitory polypeptide (GIP). Am J Dig Dis 23: 1079-1083

46. Brown JC, Dryburgh JR, Ross SA, Dupré J (1975) Identification and actions of gastric inhibitory polypeptide. Recent Progr Horm Res 31: 487-532

47. Cleator JGM, Gourlay RH (1975) Release of immunoreactive gastric inhibitory polypeptide (IR-GIP) by oral ingestion of food substances. Am J Surg 130: 128-135

48. Falko JM, Crockett SE, Cataland S, Mazzaferri EL (1975) Gastric inhibitory polypeptide (GIP) stimulated by fat ingestion in man. J Clin Endocrinol Metab 41: 260-265

49. Andersen DK, Elahi D, Brown JC, Tobin JD, Andres R (1978) Oral glucose augmentation of insulin secretion: Interactions of gastric inhibitory polypeptide with ambient glucose and insulin levels. J Clin Invest 62: 152-161

50. Ebert R, Creutzfeldt W (1984) Evidence that fat induced secretion of gastric inhibitory polypeptide is coupled to chylomicron formation. Eur J Clin Invest 14:9 A

51. O'Dorisio TM, Cataland S, Stevenson M, Mazzaferri EL (1976) Gastric inhibitory polypeptide (GIP). Intestinal distribution and stimulation by amino acids and medium-chain triglycerides. Am J Dig Dis 21: 761-765

52. Ross SA, Shaffer EH (1981) The importance of triglyceride hydrolysis for the release of gastric inhibitory polypeptide. Gastroenterology 80: 108-111

53. Tso P, Buch KL, Balint JA, Rodgers JB (1982) Maximal lymphatic triglyceride transport rate from the rat small intestine. Am J Physiol 242: G408-G415

54. Crockett SE, Cataland S, Falko JM, Mazzaferri EL (1976) The insulinotropic effect of endogenous gastric inhibitory polypeptide in normal subjects. J Clin Endocrinol Metab 42: 1098-1103

55. Ebert R, Frerichs H, Creutzfeldt W (1979) Impaired feedback control of fat induced gastric inhibitory polypeptide (GIP) secretion by insulin in obesity and glucose intolerance. Eur J Clin Invest $9: 129-135$

56. Creutzfeldt W, Talaulicar M, Ebert R, Willms B (1980) Inhibition of gastric inhibitory polypeptide (GIP) release by insulin and glucose in juvenile diabetes. Diabetes 29:140-145

57. Dryburgh JR, Hampton SM, Marks V (1980) Endocrine pancreatic control of the release of gastric inhibitory polypeptide. A possible physiological role for C-peptide. Diabetologia 19: 397-401

58. Verdonk CA, Rizza RA, Nelson RL, Go VLW, Gerich JE, and Service FJ (1980) Interaction of fat-stimulated gastric inhibitory polypeptide on pancreatic alpha and beta cell function. J Clin Invest 65: 1119-1125

59. Stöckmann F, Ebert R, Creutzfeldt W (1984) Preceding hyperinsulinemia prevents demonstration of insulin effect on fat-induced gastric inhibitory polypeptide (GIP). Diabetes 33: $580-585$

60. Dupré J, Greenidge N, McDonald TJ, Ross SA, Rubinstein D (1976) Inhibition of actions of glucagon in adipocytes by gastric inhibitory polypeptide. Metabolism 25: 1197-1199

61. Ebert R, Brown JC (1976) Effect of gastric inhibitory polypeptide (GIP) on lipolysis and cyclic AMP levels in isolated fat cells. Eur J Clin Invest 6: $327 \mathrm{~A}$

62. Andersen DK, Putnam WS, Hanks JB, Wise JE, Lebovitz HE, Jones RS (1980) Gastric inhibitory polypeptide (GIP) suppression of hepatic glucose production. Regul Pept 1 (Suppl 2): 4A

63. Ebert R, Arends J, Creutzfeldt W (1980) Insulin-dependent suppression of hepatic glucose output by GIP in the perfused rat liver. Regul Pept 1 (Suppl 2): 162 A

64. Eckel RH, Fujimoto WY, Brunzell JD (1979) Gastric inhibitory polypeptide enhanced lipoprotein lipase activity in cultured preadipocytes. Diabetes 28: 1141-1142

65. Wasada T, McCorkle K, Harris V, Kawai K, Howard B, Unger RH (1981) Effect of gastric inhibitory polypeptide on plasma levels of chylomicron triglycerides in dogs. J Clin Invest 68: 1106-1107

66. Ohneda A, Kobayashi T, Nihei J (1983) Effect of endogenous gastric inhibitory polypeptide (GIP) on the removal of triacylglycerol in dogs. Regul Pept 6:25-32

67. Creutzfeldt W, Ebert R, Willms B, Frerichs H, Brown JC (1978) Gastric inhibitory polypeptide (GIP) and insulin in obesity: increased response to stimulation and defective feedback control of serum levels. Diabetologia 14: 15-24

68. Deschamps J, Heptner W, Desjeux JF, Baltaske V, Machinot S, 
Lestradet H (1980) Effects of diet on insulin and gastric inhibitory polypeptide levels in obese children. Pediatr Res 14: 300-309

69. Elahi D, Andersen DK, Müller DG, Tobin JD, Brown JC, Andres R (1984) The enteric enhancement of glucose-stimulated insulin release. The role of GIP in aging, obesity and non-insulindependent diabetes mellitus. Diabetes 33:950-957

70. Salera M, Giacomoni P, Pironi L, Cornia G, Capella M, Marini A, Beufenate F, Miglioli M, Barbara L (1982) Gastric inhibitory polypeptide release after oral glucose: relationship to glucose intolerance, diabetes mellitus and obesity. J Clin Endocrinol Metab 55:329-337

71. Jorde R, Amland PF, Burhol PG, Giercksky KE, Ebert R (1983) GIP and insulin responses to a test meal in healthy and obese subjects. Scand J Gastroenterol 18: 1115-1119

72. Lauritsen KB, Christensen KC, Stokholm KH (1980) Gastric inhibitory polypeptide (GIP) release and incretin effect after oral glucose in obesity and after jejunoileal bypass. Scand J Gastroenterol 15: 489-495

73. Sarson DL, Besterman HS, Bloom SR (1979) Radioimmunoassay of gastric inhibitory polypetide and its release in morbid obesity and after jejuno-ileal bypass. J Endocrinol 81: 155-164

74. Service FJ, Rizza RA, Westland RE, Hall LD, Gerich JE, Go VLW (1984) Gastric inhibitory polypeptide in obesity and diabetes mellitus. J Clin Endocrinol Metab 58: 1133-1140

75. Arnold R, Creutzfeldt W, Ebert R, Becker HD, Börger HW, Schafmayer A (1978) Serum gastric inhibitory polypeptide (GIP) in duodenal ulcer disease: relationship to glucose tolerance insulin, and gastrin release. Scand J Gastroenterol 13: 41-47

76. Lauritsen KB, Moody AJ (1978) The response of gastric inhibitory polypeptide (GIP) and insulin to glucose in duodenal ulcer patients. Diabetologia 14:149-153

77. Thomford NR, Sirinek KR, Crockett SE, Mazzaferri EL, Cataland S (1974) Gastric inhibitory polypeptide. Response to oral glucose after vagotomy and pyloroplasty. Arch Surg 109: $177-182$

78. Becker HD (1980) Hormonal changes after gastric surgery. Clin Gastroenterol 9: 755-771

79. Schattenmann G, Ebert R, Siewert R, Creutzfeldt W (1984) Different response of gastric inhibitory polypeptide to glucose and fat from duodenum and jejunum. Scand J Gastroenterol 19: 260-266

80. Creutzfeldt W, Ebert R (1977) Release of gastric inhibitory polypeptide (GIP) to a test meal under normal and pathological conditions in man. In: JS Bajaj (ed) Diabetes Excerpta Medica, Amsterdam, pp 63-75

81. Crockett SE, Mazzaferri EL, Cataland S (1976) Gastric inhibitory polypeptide in maturity-onset diabetes mellitus. Diabetes 25: 931-935

82. Ross SA, Brown JC, Dupré J (1977) Hypersecretion of gastric inhibitory polypeptide following oral glucose in diabetes mellitus. Diabetes 26: 525-529

83. Ross SA, Dupré J (1978) Effects of ingestion of triglyceride or galactose on secretion of gastric inhibitory polypeptide and on responses to intravenous glucose in normal and diabetic subjects. Diabetes 27: 327-333

84. Takemura J, Seino Y, Tsuda K, Seino S, Ikeda M, Sakurai H, Imura $H$ (1981) Hypersecretion of gastric inhibitory polypeptide induced by glucose ingestion in diabetes mellitus. Endocrinology 28: $17-22$

85. Cataland S, O'Dorisio TM (1980) Pathology of gastric inhibitory polypeptide. Front Horm Res 7: 145-154

86. Perley MJ, Kipnis DM (1967) Plasma insulin responses to oral and intravenous glucose: studies in normal and diabetic subjects. J Clin Invest 46: 1954-1962

87. Raptis S, Rau RM, Schröder KE, Hartmann W, Faulhaber JD, Clodi PH, Pfeiffer EF (1971) The role of the exocrine pancreas in the stimulation of insulin secretion by intestinal hormones. Diabetologia 7:160-167

88. Ross SA, Brown JC, Dupré J (1974) Effects of gastric inhibitory polypeptide on endocrine pancreas in normal and diabetic subjects. Diabetologia 10:384A
89. Krarup T, Moody AJ, Saurbrey N, Kühl C, Madsbad S (1984) Effect of porcine gastric inhibitory polypeptide and B-cell function in Type 1 (insulin-dependent) and Type 2 (non-insulin dependent) diabetes. Diabetologia 27:299 A

90. Lauritsen KB, Lauritzen JB, Christensen KC (1982): Gastric inhibitory polypeptide and insulin release in response to oral and intravenous glucose in coeliac disease. Scand J Gastroenterol 17: $241-245$

91. Sarson DL, Wood SM, Holder D, and Bloom SR (1982) The effect of glucose-dependent insulinotropic polypeptide infused at physiological concentrations on the release of insulin in man. Diabetologia 22: 33-36

92. Sarson DL, Wood SMI, Kansal PC, and Bloom SR (1984) Glucose-dependent insulinotropic polypeptide augmentation of insulin: physiology or pharmacology? Diabetes $33: 389-393$

93. Ebert R, Creutzfeldt W (1982) Influence of gastric inhibitory polypeptide antiserum on glucose-induced insulin secretion in rats. Endocrinology 111: 1601-1606

94. Lauritsen KB, Holst JJ, Moody AJ (1981) Depression of insulin release by anti-GIP serum after oral glucose in rats. Scand $\mathbf{J}$ Gastroenterol 16: 417-421

95. Ebert R, Unger H, Creutzfeldt W (1983) Preservation of incretin activity after removal of gastric inhibitory polypeptide (GIP) from rat gut extracts by immunoadsorption. Diabetologia 24: 449-454

96. Levin SR, Pehlevanian MZ, Lavee AE, Adachi RI (1979) Secretion of an insulinotropic factor from the isolated perfused rat intestine. Am J Physiol 236: E710-E720

97. Goldberg NJ, Wingert TD, Levin SR, Adachi RI (1980) Augmentation of insulin secretion in man by a non-nutrient drink. Gastroenterology 78: 1458-1462

98. Zermatten A, Felber JP (1974) Sensitivity to glucose of an intestinal factor stimulating insulin release. Horm Metab Res 6: 272-274

99. Moody AJ (1977) Insulin releasing polypeptides. In: JS Bajaj (ed) Diabetes, Excerpta Medica, Amsterdam, pp 76-82

100. Rojdmark S, Bloom G, Chou MCU, Field JB (1978) Hepatic extraction of exogenous insulin and glucagon in the dog. Endocrinology 102: 806-813

101. Faber OK, Hagen C, Binder C, Markussen J, Naithani VK, Blix PM, Kuzuya H, Horwitz DL, Rubenstein AH, Rossing N (1978) Kinetics of human connecting peptide in normal and diabetic subjects. J Clin Invest 62: 197-203

102. Polonsky KS, Rubenstein AH (1984) C-peptide as a measure of the secretion and hepatic extraction of insulin: pitfalls and limitations. Diabetes 33: 486-494

103. Gibby OM, Hales CN (1983) Oral glucose decreases hepatic extraction of insulin. Br Med J 286: 921-923

104. Madsbad S, Kehlet H, Hilsted J, Tronier B (1983) Discrepancy between plasma C-peptide and insulin response to oral and intravenous glucose. Diabetes 32: 436-438

105. DeFronzo RA, Ferranini E, Hendler R, Wahren J, Felig P (1978) Influence of hyperinsulinemia, hyperglycemia, and the route of glucose administration on splanchnic glucose exchange. Proc Natl Acad Sci USA 75: 5173-5177

106. Polonsky KS, Jaspan J, Pugh W, Cohen D, Schneider M, Schwartz T, Moossa AR, Tager H, Rubenstein AH (1983) Metabolism of $\mathrm{C}$-peptide in the dog. In vivo demonstration of the absence of hepatic extraction. J Clin Invest 72: 1114-1123

107. Ishida T, Lewis RM, Hartley CJ, Entman ML, Field JB (1983) Comparison of hepatic extraction of insulin and glucagon in conscious and anaesthetized dogs. Endocrinology 112: 1098-1109

Prof. Dr. med. W.Creutzfeldt

Medizinische Universitätsklinik

Robert-Koch-Straße 40

D-3400 Göttingen

FRG 